\title{
Sociolinguistic Perspectives on the Implications of the Homogenization of the Circles of World Englishes
}

\author{
Christiaan Prinsloo ${ }^{1}$ \\ ${ }^{1}$ Faculty of Liberal Education, Seoul National University, Seoul, South Korea \\ Correspondence: Christiaan Prinsloo, Faculty of Liberal Education, Seoul National University, Seoul, \\ South Korea. E-mail: christiaanprinsloo@gmail.com
}

Received: September 6, 2017 Accepted: September 22, $2017 \quad$ Online Published: October 25, 2017

doi:10.5539/ijel.v8n1p1 URL: https://doi.org/10.5539/ijel.v8n1p1

\begin{abstract}
The marginalization of English second (L2) and foreign language (EFL) users in the academic and practical pursuit of English language teaching (ELT) has fueled the hegemonic power of the inner circle of world Englishes (CWE). Because of the inequality among the circles of world Englishes, this paper pursues a dual purpose: firstly, it sets out to determine the sociolinguistic effects of globalization on the CWE; and secondly, it establishes how these sociolinguistic effects contribute to the homogenization of the circles and a seemingly more equitable notion of (world) English(es). Drawing on available qualitative descriptions and empirical data, three practical contexts of sociolinguistics were identified (viz. demographic shifts, economic motivations, and language education policy) to realize the dual research purpose. Based on a qualitative instrumental case study of a purposive sample of one country from each CWE, the study assesses the possibility to justify the proposition that the functions of English across the circles are becoming more similar as globalization homogenizes the global English sociolinguistic ecology. The findings support claims of major evolutionary processes that entail significant implications for the ELT community across the CWE.
\end{abstract}

Keywords: CWE, sociolinguistics, globalization, English language teaching, homogenization

\section{Introduction}

The proliferation of English is intricately connected with international politics, economic power relations, technological developments, and cultural influences (Crystal, 2012; Phillipson, 1998). As Britain ruled the waves prior to World War II, its colonial empire transmitted the English language to the far reaches of the globe whilst colonies capitulated to British law, commerce, and education (Pennycook, 2002). A one-size-fits-all type of globalization characterizes this preindustrial and industrial era imposition and propagation of international power networks and subaltern struggles for emancipation and identity (Warschauer, 2000).

Today, the subaltern is still embroiled in struggles for recognition and a plight to escape from the oblivion imposed by their membership to the nonnative English-speaking community. The most poignant and sobering critique is delivered by Kumaravadivelu (2014) in a pensive reflection on the standing of nonnative English speakers in the ELT community:

[...] English language teaching [...] is the proud privilege of the expatriates from the United Kingdom and the United States [...] (Kumaravadivelu, 2014, p. 68).

Seldom in the annals of an academic discipline have so many people toiled so hard, for so long, and achieved so little in their avowed attempt at disrupting the insidious structure of inequality in their chosen profession [ELT]. In countering hegemonic forces, the subaltern intellectuals have so far proved to be no more than ineffectual angels beating their wings in the void [...] The question is: Can the subaltern act? (Kumaravadivelu, 2014, p. 82).

The marginalization of English second (L2) and foreign language (EFL) users (or the nonnative subaltern) in the academic and practical pursuit of ELT, over the past circa three decades, has fueled the hegemonic power of the inner circle of world Englishes (CWE). While Kumaravadivelu (2014) considers the subaltern from a personal, reflective perspective, this paper assumes a global perspective facilitated though the globalization narrative and the CWE. The CWE has become more than a model to explicate indigenized varieties of English, as it became indicative of intrinsic power relations maintained by unequal global undercurrents. Because of the perceived 
inequality among the CWE, this paper pursues a dual purpose:

1) it sets out to determine the sociolinguistic effects of globalization on the CWE, and

2) it seeks to establish how these sociolinguistic effects contribute to the homogenization of the circles and a seemingly more equitable notion of (world) English(es).

The following chain of thought anticipates the strategy to realize the dual purpose: The introduction is followed by an integration of literature that contextualizes the proliferation of English within the relevant strands of the globalization narrative, and in doing so it assumes a global perspective. The third part describes and justifies the model of the CWE as the qualitative instrumental case study design. In part four, a local perspective is assumed to report on the effects of globalization on the cases of the instrumental case study. The practical contexts of sociolinguistics (viz. demographic shifts, economic motivations, and language education policy) are used to account for the homogenizing effect of globalization. Part five considers the implications for the ELT community of the evolving functions of English and the homogenization of the CWE. The paper concludes with directions for future research.

\section{Globalization of the English Knowledge Economy}

The current proliferation of English across the globe is unparalleled in the diachronic history of world languages (Crystal, 2012; Feng, 2012), but it does not mean that English is the only world language (Benrabah, 2014). The global presence of English is becoming more pronounced as L2 and EFL users vastly outnumber "native" or first language (L1) users (Warschauer, 2000). Scholarship theorizes the spread of English as colonization, globalization, and internationalization and contributes to complex narratives about the evolving functions of English as a world language (Benrabah, 2014) and global lingua franca (McArthur, 2001). The imbalanced power distribution among English and other languages (Benrabah, 2014; Feng, 2012), standardized English (McArthur, 2001; Widdowson, 1994), and other varieties and registers of English (Gardner, 2012; Norton, 1997) summon linguistic imperialism to the discourse.

The spread of English is deeply rooted in American and British political and economic interests; therefore, views of English linguistic and cultural imperialism abound (Benrabah, 2014; Canagarajah, 1999; Choi, 2003; Kumaravadivelu, 2014; Modiano, 2001; Phillipson, 1996, 1997; Pennycook, 1996). To some, the "Trojan horse" of English evokes apprehension (Cooke in Peirce, 1989, p. 402); however, to others it could be as magical as “Aladdin's lamp" (Kachru in McKay, 2003, p. 4; see Giri, 2014; Sung-Yul Park \& Lo, 2012).

Although not readily recognized as colonization, the contemporary globalization of American and British sociocultural products (English included) occurs through the homogenization of stable, progressive economies. "The 'electronic herd' moves vast amounts of capital in and out of countries according to their political and economic merits. [...] States can defy the 'herd', but they will pay a price, usually a steep one, as did Thailand, Malaysia, Indonesia and South Korea in the late 1990s" (Waltz, 2000, p. 47). In contrast to vehement preindustrial colonization, postindustrial globalization is characterized by the economically motivated relocalization of one-size-fits-all socioeconomic products, such as the regional versions of MTV (Warschauer, 2000) and the English knowledge economy or informationalism.

The knowledge economy is associated with interlocking multilateral networks of commerce, science, education, and entertainment stitched together by the Internet (Warschauer, 2000) and facilitated to a large extent in/by English (Seargeant \& Tagg, 2011). English has permeated numerous areas of the international information-based industry particularly in educational and business settings (Altbach, 2004; Crystal, 2012; Jenkins, Cogo, \& Dewey, 2011; Nickerson, 2005). The knowledge economy is synonymous with the transnational trade of higher education (Knight, 2004) as Western universities (predominantly from the inner CWE) vigorously pursue budding international educational markets (Bovill, Jordan, \& Watters, 2015; Knight, 2015; Wildavsky, 2010). Depending on one's perspective, these pursuits may lead to pernicious and/or auspicious results as national contexts of higher education surrender to and/or accommodate the standards and practices of international English-medium universities (Phillipson, 1998; Olds, 2007). However, Altbach (2004) is of the opinion that the knowledge economy contributes to and exacerbates the unequal relations in international education. This reinforces the dependence of universities in the outer and expanding CWE on universities in the inner circle.

The relocalization of Western universities in foreign markets could be seen as a consequence of the contemporary emphasis on the English knowledge economy (Cooper, 2006; Olssen \& Peters 2005) and the unsustainable profitability of higher education (Guruz, 2011). Cooper (2006) draws on the variables of the Knowledge Assessment Methodology developed by the World Bank to assess the readiness of Brazil, China, India, Russia, and South Africa (the BRICS nations) to evolve into knowledge-based economies. Within national 
borders, knowledge economies develop without English; however, globalization and participation in international trade and education oblige the use of English. As a result, StudyPortals determined that "the number of university courses taught in English in non-English-speaking countries has increased by more than $300 \%$ in seven years" as more than 2100 universities around the world are offering 72,000 courses taught in English (in Mitchell, 2016). These English-mediated courses are taught by approximately $80 \%$ of the global teacher population who are nonnative speakers of English (Snow, Kamhi-Stein, \& Brinton, 2006).

The increased demand for English instruction serves as incentive for ELT to respond with a textbook industry that proliferates specialized inner circle pedagogies (Paltridge, 2007) and "center-based methods" (Kumaravadivelu, 2014, p. 81). Kumaravadivelu (2003, p. 565) considers it as a "vice-like grip the Anglo-American textbook industry has on the global ELT market" that proliferates Western (inner circle) values and economies (see Forman, 2014, p. 72). These pedagogies and textbooks could be criticized as "form[s] of domination, supporting the spread of English, and thus strengthening, in EFL settings, the hold of the developed world on the less developed world, and in ESL [English as a Second Language] settings, aiding and abetting a too pervasive melting-pot process that effaces cultural identity" (Belcher, 2006, p. 143).

Although ELT could pursue pragmatic aims to inculcate learners as autonomous English language users through English for Specific or Academic Purposes (ESP or EAP), for example, these pedagogic approaches remain relatively unconcerned with the profound global power relations of ELT across the CWE. Such pedagogies should not maintain "genres of power" to assimilate L2 and EFL users into Western thought (Kratz, 1989, p. 636). To overcome conformity with "vulgar pragmatism", Pennycook (1997, p. 258) suggests awareness of the epistemological and cultural norms that accompany the spread of English. Critically conscious teachers and scholars should consider that ELT summons and repels opportunities and experiences as learners appropriate English for unique individual purposes (Belcher, 2006). Regardless of being relatively uncritical, ESP and EAP will continue to succeed in socializing learners into diverse communities (Hyland, 2010) because fluency in English is essential to gain access to the academic community (Hyland, 2004) and global knowledge economy (Guruz, 2011). It is for this reason that Kumaravadivelu (2014) urges the subaltern to rely on local professionals to design context-specific pedagogies, produce their own pedagogic knowledge, and conduct proactive research. These suggestions reverberate postmodern incredulity toward metanarratives (Lyotard, 1984). This section has illustrated that the metanarrative of English globalization has permeated ELT ideologically, economically, and pedagogically.

\section{Methodology: CWE as Instrumental Case Study}

The research design of this paper is logical and consists of a collective case that is based on Kachru's three CWE; therefore, it would be prudent to elaborate on the composition of Kachru's original model.

In an attempt to come to terms with indigenized varieties of English, Kachru (1990a, 1990b, 1996) conceptualized the "pluricentricity" of English as three concentric CWE (see Figure 1). The inner circle consists of countries where English is the official language, and it functions as the norm-providing L1 in countries, such as Australia, Britain, and the United States of America (USA). English is recognized as official language when it is used as the primary medium of communication in government, business, media, and education (Crystal, 2012). The outer circle denotes countries, often those with colonial histories, where English functions as norm-developing L2. Examples of such countries include India, Hong Kong, and South Africa where English, in addition to other languages, serves as an official language. The expanding circle represents countries where English is not recognized as an official language, and it serves a norm-dependent function, for example in China, Japan, and South Korea. 


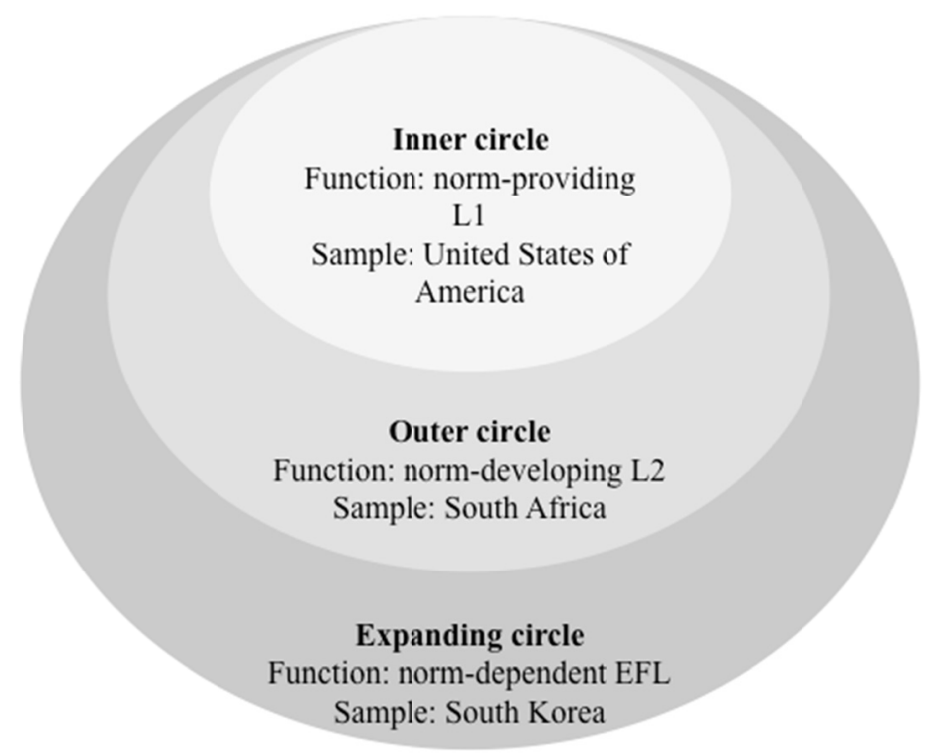

Figure 1. Three circles model of world Englishes (based on Kachru, 1990a, p. 4)

In general, the model serves sociolinguistic and taxonomic purposes by ascribing the hierarchical linguistic functions of English in/for each circle, viz. norm-providing, norm-developing, and norm-dependent. Seargeant and Tagg (2011, p. 498) point out that the original plural form world Englishes "did much to break down the myth of a single monolithic English language, and thus better reflect the "sociolinguistic realities" of postcolonial territories where the language now exists as an established part of the linguistic ecology."

In this paper, the model serves a methodological function as structure for an instrumental case study that focuses on a broader phenomenon than the case itself (Dörnyei, 2007). While the original focus (or case) of the model was English, it functions methodologically as platform for the larger globalization narrative that involves "sociolinguistic realities" affected by world Englishes. A purposive sample of three countries was chosen, not to represent all the countries from each circle, but rather to concretize the effects of globalization within and across the circles. The following countries were drawn on from each circle: the USA from the inner circle, South Africa from the outer circle, and South Korea from the expanding circle. Secondary empirical data from reputable sources, such as national census bureaus, were used to describe the sociolinguistic ecology and the repercussions of globalization on the functions of English across the CWE.

\section{Effects of Globalization on the CWE}

The effects of globalization that propel the evolution of English could be illustrated by tracing the instrumental, regulative, interpersonal, and innovative functions that English performs in a society as Giri (2014) illustrates in the case of Nepal. Similarly, Ricento's (2000) diachronic perspective of the three phases of language policy is illustrative of the changing profile of English. Phase one, from the 1960s through 1970s, was concerned with "standardization, graphization, and modernization" of language policy (Ricento, 2000, p. 202). "A widely held view among Western(ized) sociolinguists in this period was that linguistic diversity presented obstacles for national development, while linguistic homogeneity was associated with modernization and Westernization" (Ricento, 2000, p. 198). The second stage, from the early 1970s through late 1980s, witnessed the hierarchization and stratification of populations and the social, economic, and political effects of language contact (Ricento, 2000). The third phase, from the 1980s to the present, is characterized by global migration, linguistic diversity (Ricento, 2000, p. 204) and in postmodern terms, the recognition of local narratives (Lyotard, 1984).

This paper draws on what Kachru (1990a, p. 11) calls the "local (domesticated) pragmatic contexts" of each case. These pragmatic contexts of sociolinguistics include demographic shifts, economic motivations, and language education policies. Because this paper assumes a global perspective across the CWE, the pragmatic contexts of sociolinguistics maintain such wide-angle perspective while simultaneously unpacking the relevant local narratives of the instrumental case study.

\subsection{The Inner Circle}

As used in the inner circle, English as a first language (L1) can be defined as the norm-providing language that 
sets the linguistic norms of what may be considered standardized English. As such, it determines the national sociolinguistic identity of a population. In countries such as the USA, political, professional, and educational interactions are conducted primarily in English, regarded as the L1; therefore, English is acknowledged as the de facto official language (Kachru, 1996). The official standing of standardized English in the USA is susceptible to scrutiny when the effects of demographic shifts, language education policies, and economic developments are considered.

Demographic statistics indicate that the number of L2 and EFL English speakers in the USA is drastically increasing. The population of native English speakers increased by $22.7 \%$ between 1980 through 2013. In contrast, the population of L2 and EFL speakers increased by $158.2 \%$ for the same period (Ryan, 2013). In 1980 the L2 and EFL population accounted for only 11\% of the total population. By 2013 the L2 and EFL population has grown to $20.7 \%$ of the total population (Ryan, 2013). According to the United States Census Bureau (2016), the L2 and EFL population uses 303 languages at home, other than English. Although the L1, L2 and EFL populations may recognize their national identity as Americans, the linguistic diversity reveals sociolinguistic identities that are vastly different from the national identity.

The USA could be described as "a nation of immigrants" and at "present relies on immigration" (Pedraza, 2006, p. 426); however, contemporary and future political developments leave such claims in flux. Because of large-scale immigration, language in education has been an issue at least since 1968 when Title VII, the Bilingual Education Act, created space for bilingual education and support in a learner's heritage language. The period of support was extended from three to four or five years in 1994 and preference was given to "programs that sought to develop students' native-language skills while simultaneously fostering English language proficiency" (Evans \& Hornberger, 2005, p. 88). However, in 2002, the No Child Left Behind Act introduced English language development as a condition without which academic progress is not possible. While language was considered as a recourse or right, the No Child Left Behind Act considers language and bilingual education as problems. The current No Child Left Behind Act problematizes bi-/multilingualism in the L1 context and is reminiscent of Ricento's (2000) phase-one language policies of the 1960s through 1970s that cultivated national linguistic homogenization. Heritage languages become facilitative of English learning (Evans \& Hornberger, 2005), and they may even promote the objectives of the English-only movement (García, 2005). Consequently, cultural and linguistic assimilation of EFL-speakers has remained a common objective of immigration (Pedraza, 2006) and education policies in the USA (Ricento, 2000).

With decreased recognition of the functions of heritage languages in the academic domain, the English-only movement and ELT are subject to scrutiny. Tse (2001, p. 33) argues that "[k]nowing English and knowing it well is of course important, but monolingualism is not the only path to achieving fluency in the language, a point missed by those who see English and English only as the sole path." Or as García (2005, p. 605) argues "[o]ur multiple identities have been silenced, with one language identity reduced to that of a heritage" (original emphasis). As the L2 or EFL population increases in the USA, linguistic diversity and residents with limited English proficiency also increase (Pandya, McHuge, \& Batalova, 2011). Proponents of the heritage language loss debate argue that proficiency in the native language of the country of origin erodes because of pressure to learn English not necessary to become bilingual but to replace their original L1 (Tse, 2001). The loss of heritage languages and bilingualism proliferate the "solitude" of standardized English that globalizes the world (García, 2005, p. 605).

Failure to master the standardized variety of English of the inner circle through ELT is directly connected to earning capacity. Based on USA census data, Bleakley and Chin (2004, p. 493) found "a significant positive effect of English-language skills on wages [...]" that is coupled with increased years of English schooling. Grenier (2015) estimates the earning advantage of people who are fluent in the dominant language at approximately $10-20 \%$ compared to nonfluent users. Currently, approximately $10 \%$ of K-12 students (and by 2025, 25\%) will need ELT (or EAP) assistance to cope with "grade-level academic content" (Kanno \& Cromley, 2013, p. 89). However, ELT does not seem to hamper foreign-born English-language learners in the USA from acquiring the needed linguistic skills. These skills are mastered and on par with American-born English-language learners by the end of high school (Slama, 2012). As illustrated in Figure 2, earning capacity manifests at college/university-level where one in eight (12.5\%) EFL, one in four (25\%) English proficient students, and one in three (33.33\%) English monolingual students earn bachelor's degrees (Kanno \& Cromley, 2013). It would be imprudent to consider ELT as the only factor that contributes to earning capacity as parental support, academic underpreparation, financial need (Kanno \& Cromley, 2013), age, gender, region of origin, and region of relocation (Kulkarni \& $\mathrm{Hu}, 2014$ ) could also affect the learning of English, future educational success, and eventually earning capacity. It is clear though that ELT at a young age is more advantageous because Bleakley 
and Chin (2004) suggest that adult L2/EFL classes may be inadequate to help immigrants earn similar wages as native speakers of English.

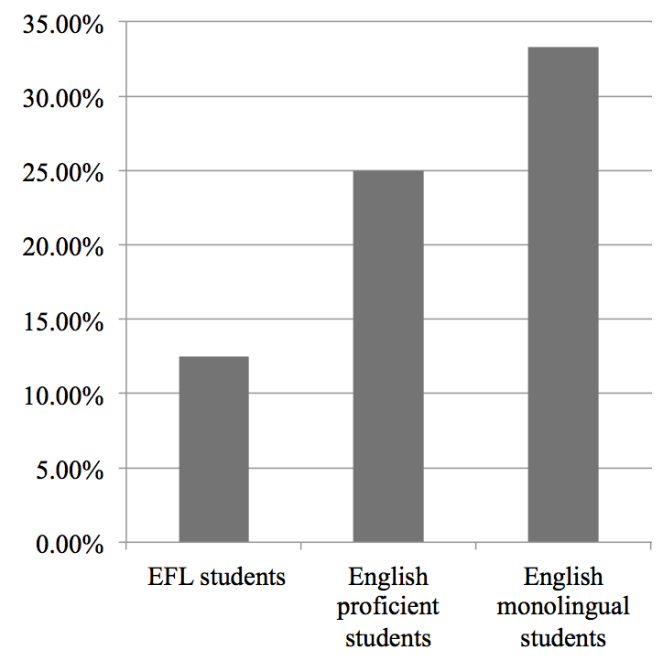

Figure 2. Earning capacity expressed through student populations that earn bachelor degrees

The function of English in the USA is influenced by the pragmatic contexts of sociolinguistics that are embroiled in oscillating relationships. The burgeoning demographic diversity of the USA challenges language education policy and signals an evolution toward the multilingual composition of the inner circle. If the USA recognized a multilingual language policy, then its norm-providing status may become threatened because its language policy would be similar to that of countries in the outer circle, such as South Africa. From an inner circle perspective, it may therefore not evolve but perhaps devolve to the outer circle. Because of its vested economic interest in the English knowledge economy and ELT industry, the bastion of "real English" (Seidlhofer, 2004, p. 213) is understandably reluctant to relinquish its English norm-providing role by embracing multilingual educational policies. Consequently, demographic diversity seems to be the primary force challenging the inner circle norm-providing role.

\subsection{The Outer Circle}

Although the outer circle is generally recognized as a norm-developing L2 setting, this does not necessarily signify the sociolinguistic identity of the general population, which may prefer another language as native or mother tongue for its linguistic identity. In the past, South Africa belonged to the expanding circle of world Englishes and was norm-dependent on its British colonizers. In contemporary South Africa, English is used abundantly in political, professional, and educational interactions. It is worth noting that English (not as L1, L2, or EFL) played a pivotal political role to advocate against the predominantly Afrikaans-speaking apartheid regime (Peirce, 1989). As such, English is not regarded as a variant belonging to the L2, outer circle of world Englishes with characteristic syntax, semantics, or phonetics; instead, it can be conceived of as an emancipatory language (Heugh, 2015) that provides access to the global community and accomplishes sociopolitical action, hence its name People's English (Peirce, 1989).

Indeed, People's English reflects the accommodationist philosophy of the Constitution of the Republic of South Africa (No. 108 of 1996) that recognizes English as only one of the 11 official languages. During its colonial and apartheid history, South Africa has experienced biased ethnolinguistic policies that advocated a unified national and ethnic identity through a one language-one nation ideology borrowed from Europe (Heugh, 2015). However, contemporary South African linguistic history is significantly affected by the power of the Constitution and bilingual, intercultural education. South Africa has proven and auspicated that the ideology of one language-one nation is too myopic and prejudiced for its multilingual and multicultural aspirations.

The Constitution may advocate linguistic pluralism and English may have facilitated political transition when other languages were entangled in segregationist power relations; however, post-apartheid demographic and sociolinguistic research challenges such perspectives. The post-apartheid government adopted a progressive Language-in-Education Policy that delegates the choice of language instruction to individual schools. The policy 
promotes bilingualism as schools are encouraged to use African languages in conjunction with English. However, a majority of schools favor English for pedagogic purposes from grade four through twelve (Casale \& Posel, 2011, p. 387). Kamwangamalu (2000) argues that education in an African language is destined to fail partially because of the apartheid-induced stigma that such education is inferior. More significantly, though, "[t]he demand for English is exacerbated by the fact that [...] pupils are only too well aware of the power of English to ask for education in any other language, and of the fact that their own languages have no economic cachet neither locally nor internationally" (Kamwangamalu 2000, p. 55). In 2016, violent language protests swept over several South African university campuses. Language policy makers responded by paying heed to the demands of students for English-only instruction at these institutions (Makoni, 2016). These policy changes affirm the evolutionary process within the outer circle to maintain its norm-developing function and evolve toward becoming more norm-providing.

As "the language of upward mobility and access" (Probyn, 2009, p. 126), English is favored over the other official languages despite being recognized as "equal" by the Constitution. Upward demographic mobility is confirmed by Casale and Posel (2011, p. 392), who found that English proficiency among African men with post-secondary education resulted in approximately $90 \%$ better earnings. The inequality among and impracticality of the other official languages is accentuated by the notion that "for men who do not have good English language skills, there are no independent economic advantages to being proficient in an African language" (Casale \& Posel, 2011, p. 391). Without earning capacity in the "real world", the Constitution and Language-in-Education Policy cannot ensure equality among the 11 official languages.

The overwhelming favor of English in education, broadcasting, the government, judicial system, and military (Kamwangamalu, 2000) are in stark contrast with the sociolinguistic composition of South Africa. English is the L1 of only $9.6 \%$ of the total population. IsiZulu is by far the majority language used as L1 by $22.7 \%$ followed by IsiXhosa (16\%) and Afrikaans (13.5\%) (Statistics South Africa, 2011). Despite not being the majority L1 language, a post-apartheid sociolinguistic evolution has been occurring directed "almost exclusively towards English [...]" (Deumert, 2010, p. 32).

South Africa's multicultural demographic population and multilingual language education policy suggest relative stability of these pragmatic sociolinguistic contexts. However, the earning capacity of English in South Africa is similar to this dimension of the sociolinguistic ecology of the USA, which suggests that English proficiency may continue to earn higher wages in the outer circle of world Englishes. A similar trend is identified in India, which could be compared with South Africa as an outer circle territory. Azam, Chin, and Prakash (2013, p. 365) found: "[h]ourly wages are on average 34\% higher for men who speak English fluently and $13 \%$ higher for men who speak a little English relative to men who speak no English. For women, the average returns are $22 \%$ for fluent English and 10\% for a little English."

The evolving sociolinguistic ecology of South Africa that supports multilingualism through language education policy could signal future pathways for the expanding circle of world Englishes.

\subsection{The Expanding Circle}

The third example is drawn from South Korea in the expanding circle where English is recognized as EFL and accounts for the evolution toward being recognized as L2 context (Seidlhofer, 2004). A similar argument is made by Giri (2014, p. 192) who demonstrates convincingly that "English is not a foreign language in Nepal." In the expanding circle, English is primarily regarded as foreign language that is norm-dependent on the inner circle, and it is neither recognized as the official language nor the sociolinguistic identity of the population. In monolingual South Korea, the use of English in the domain of informationalism is relatively limited, yet increasing. Despite efforts to increase the official status of English in government, Korean (Hangul) remains the sole official language (Song, 2011; Yoo, 2005).

In contrast with the linguistic heterogeneity of South Africa that initially used English to escape political persecution and suppression, a linguistically homogenous South Korea has been using English primarily for socioeconomic reasons. The linguistic ecology and economy of South Korea was significantly influenced by five diachronic developments: (1) the Seoul Olympics in 1988 spurred a flurry of wealthy parents to send young children overseas for early English language education; (2) in 1991 compulsory English language courses were introduced in all elementary schools; (3) in 1994 university entrance examinations incorporated communicative competence testing in addition to grammar; (4) by the late 1990s an English listening test was added to the government entrance examination (Park, 2009); and (5) in 2008 the Presidential Transition Committee introduced English-only instruction for English language course, mathematics, and some science courses (Jeon, 2012). 
Although these developments could in part be explained as a result of globalization and government initiatives to internationalize South Korean society, especially after the 1997 International Monetary Fund Crisis (Park \& Abelmann, 2004), "English has been recruited, in the guise of globalization, to exploit the meretricious ideology of merit to the advantage of the privileged classes and to the disadvantage of the other classes of the society" (Song, 2011, p. 35; see Sung-Yul Park \& Lo, 2012, p. 150). At approximately US $\$ 15.8$ billion annual expenditure, South Koreans invest substantially in English education domestically and abroad (Park, 2009; Jeon, 2012) to gain "valued linguistic and cultural capital" (Sung-Yul Park \& Lo 2012, p. 148). Comparing it with Taiwan can contextualize South Korea's expenditure. With approximately half the population of South Korea, Taiwan spends only between US\$680-828 million on English education (Feng, 2012, p. 365). This means that South Koreans spend approximately 10 times more on ELT than Taiwanese who also belong to the expanding circle of world English.

This educational advantage, however, may come at the cost of the Korean sociolinguistic national identity that was cemented after the collapse of Japanese colonial rule on the peninsula (Yoo, 2005). Consequently, "the idea of what it means to be South Korean is transforming: increasingly, to be South Korean means to be South Korean 'in the world' - a prospect that calls for the mastery of English as an index of cosmopolitan striving" (Park \& Abelmann, 2004, p. 650). On the one hand, English may be seen as a liberator for the more than seven million Korean diaspora in foreign countries (Sung-Yul Park \& Lo, 2012, p. 148); on the other hand, the financial, linguistic, and cultural costs associated with the English industry contribute to the maintenance of hierarchical power relations in South Korea (Song, 2011). Hu (2005) provides a thorough exposition of similar socioeconomic influences on the propagation of ELT in the Chinese context; for example, proficiency in English is also considered a national and personal asset (Hu, 2005, pp. 5-6). Consequently, similar to South Korea, China introduced compulsory English instruction in primary education, encounter shifts in pedagogic approaches, and witnesses the creation and maintenance of hierarchies based on access to English education (Hu, 2005, pp. 18-21).

The burgeoning South Korean economy acts as magnet for a rapidly increasing migrant population. Approximately three percent of the total population or 1.5 million foreigners reside in South Korea (Jun \& Ha, 2015; Park, 2014; Kim, 2009). Indeed, South Korea is fast becoming an immigrant-receiving country (Park, 2014); however, this trend could be hampered by political turmoil on the peninsula. Kim (2009) argues that migration to South Korea is on par with international migration trends, namely that migration is increasing, accelerating, diversifying, affecting more women, and becoming progressively more politicized. According to $\operatorname{Kim}(2009$, p. 90), as the monoethnic and monolingual character of South Korea changes, the initial "control and management" government policy regarding migrants becomes more accommodationist to reflect multicultural "understanding and respect" that embraces the spread of English on the peninsula.

Contemporary language policy in South Korea advances the agenda of third phase language policy and planning by actively promoting ELT in the EFL context. However, South Korea remains in the norm-dependent expanding circle. It is uncertain whether the presence of English in a territory for at "least a century" is indeed necessary to validate membership to the L2, outer circle (McArthur, 2001, p. 8). Official recognition, implementation through national language policy, and use in different realms of society may suffice to initiate an evolution toward the outer circle (see Giri, 2014).

Continued motivation for the proliferation of English in South Korea is found in the globalization narrative. "Contemporary Korean's focus on acquisition of the global language of English reminds sociolinguists that global multilingualism is not simply a cultural effect of globalization, but a key force that drives globalization, pushing us to accord a much more central position to language in our exploration of the global world" (Sung-Yul Park \& Lo, 2012, p. 151). As South Korea continues to embrace ELT through official education policy, more young Koreans become proficient in English and thus systematically convert the domestic language ecology from EFL context to English L2 context. As South Korea expands its mandate for international education (Jon, Lee, \& Byun, 2014), its migrant bi-/multilingual population would continue to increase. Therefore, South Korea's English norm-dependence may be temporary, as it evolves to become norm developing.

Kachru theorizes the sociocultural dimensions of nativized styles and discourses of English used outside the inner circle by arguing that the writer in the outer circle is bi-/multilingual but not necessarily bi-/multicultural. Therefore, "he/she is using English in a context which gives the language a new linguistic and cultural identity" (Kachru, 1990a, p. 11). However, this phenomenon occurs across the CWE. English is given a new linguistic and cultural identity in the inner circle as a growing portion of the population becomes more diverse and thus $\mathrm{bi}-$ /multilingual. English is given a new linguistic and cultural identity in the expanding circle as ELT increases bi-/multilingualism (see Giri, 2014). Therefore, the new linguistic and cultural identities created and assumed in 
the inner and expanding circles become reflective of the multilingual and multicultural identities of the outer circle. The new demographic normal is one of multiculturalism that steadily homogenizes the global ELT population. Table 1 provides a rudimentary, yet effective, illustration of this evolution. The arrows $(>)$ signal the evolution in the direction of the circle of world Englishes to which they point, and the circles $(\mathrm{O})$ suggest relative inertia.

All three circles propagate ELT based on increased earning capacity, suggesting that financial motivations attached to the proliferation of world Englishes are similar across the circles. While the inner and outer circles experience relative language education policy inertia, the expanding circle shows evolution toward the multilingual policies of the outer circle. Together with current unfolding global migration patterns, the future may be destined to settle on multilingual education policy that is prevalent in the outer circle (see Table 1).

Table 1. The evolving functions of English across the CWE.

\begin{tabular}{llll}
\hline & $\begin{array}{l}\text { Categories of world Englishes } \\
\text { Inner circle }\end{array}$ & Outer circle & Expanding circle \\
\hline $\begin{array}{l}\text { Initial functions in world Englishes } \\
\text { model }\end{array}$ & Norm-providing function & Norm-developing function & Norm-dependent function \\
Shifting function in sociolinguistic & & & \\
contexts & $>$ & & \\
$\begin{array}{l}\text { Demographic shifts } \\
\text { Economic motivations }\end{array}$ & $\mathrm{O}$ & $\mathrm{O}$ & $<$ \\
Language education policy & $\mathrm{O}$ & $\mathrm{O}$ & $<$ \\
\hline
\end{tabular}

The sociolinguistic processes in Table 1 depict cardinal shifts in the functions of English across the circles as the outer and expanding circles become more norm-independent from the inner circle, whilst the inner circle may be losing its hold on the norm-providing function. Paradoxically, because of the globalization of Western sociocultural products, the outer and expanding circles begin to use English to claim their shares in the knowledge economy through the collaboration and internationalization of education (Jon et al., 2014; Mitchell, 2016). However, Altbach (2015, p. 4) cautions that "[a]cademic collaboration, intellectual exchange, and internationalization are ancillary to the main purpose of the enterprise-money." Consequently, with its roots in colonization, the globalization narrative continues to nurture linguistic and cultural imperialist sentiments that configure the hierarchy of English norm-dependence on the inner circle that has a stronghold on the knowledge economy, thus legitimizing concerns of "multi-level supremacy" of the West (inner circle) over the Rest (outer and expanding circles) (Kincheloe, 2008, p. 2). Globalization is not inherently pernicious, but the linguistic and cultural imperialist strands that lead to the "inequitable distribution of its benefits" cause reason for discontent (Hornberger \& Vaish, 2009, p. 316).

\section{Implications}

What are the possible implications of the homogenization of the CWE for the ELT community? The implications (recommendations) envisioned here are congruent with the global (collective) perspective initiated in part two. While I agree with Kumaravadivelu's (2014) call to action of the subaltern, such call could also be (mis)construed as antagonistic toward the inner circle of world Englishes. Instead, the global perspective attempts to assign rectifying responsibility across the CWE.

\subsection{Obfuscation of Rigorous Distinctions Among L1, L2, and EFL}

Demographic shifts across the CWE indicate that nationality is not indicative of citizens being English L1, L2, or EFL users. As populations across the circles become more multilingual the rigorous attribution of L1, norm-providing status to the inner circle; L2, norm-developing status to the outer circle; and EFL, norm-dependent status to the expanding circle become less significant and obfuscated. Although it was purposeful and didactical at the time of its conception, the taxonomizing function of the CWE is being outpaced by globalization, and an alternative flexible model should to be conceived.

\subsection{Reevaluation of ELT Methodologies}

Because of the obfuscation of the rigorous distinctions among L1, L2, and EFL, the applicability of ELT methodologies across the circles should be reevaluated continually. For example, the excessive focus on communicative competence for language learning in EFL settings may frustrate learners because the population that requires English language learning (as opposed to acquisition) is slowly but steadily shrinking, while the 
English knowledge economy simultaneously drives the need for specialized English language learning. Few people, if any, are born into any specialized register of English, such as legal or technical English. This may signal that ESP and EAP are destined to continue their pedagogic and methodological proliferation across the CWE.

\subsection{Equalization among Varieties of World Englishes}

Corresponding with Ricento's (2000) first and second phases of English standardization and hierarchization, respectively, colonization and globalization produced the notion of a superior inner circle-variety that could be learned through L2/EFL pedagogies. Emblematic of postmodernism, the third phase challenges the notion of a superior hierarchy. As English is relocalized, world Englishes assumes an inherent bi-/multilingual character, such as the Nepalization of English (Giri, 2014). This proliferating hybrid variety is used by L1, L2, and EFL speakers across the CWE in domestic and international settings (see Seidlhofer, 2004). Therefore, ELT does not have to aspire to acquire and impart the "native" variety.

The challenge to the inner circle norm-providing standard is currently witnessed in the recognition of local varieties of English in academic journals, for example. The Journal of English as a Lingua Franca, the International Journal of Law, Language, and Discourse, and the International Journal of Legal English encourage submissions in regional varieties of English. The editorial policy that requires contributions to be "screened" by "native speakers" of English is also relinquished by other journals (Jenkins et al., 2011, p. 301). The recognition of local English variants in academic journal settings signals the challenge to the dominant knowledge economy.

\subsection{Challenges to the Knowledge Economy}

To a large extent, academia functions as the gatekeeper of the ontological and epistemological underpinnings of global progression or regression. Among others, academic journals are the mouthpieces that screen and proliferate such knowledge. This knowledge is transmitted primarily in "standard" English. However, officially recognizing and encouraging varieties from the periphery challenges the powerful metanarrative of standardization and hierarchization as the varieties begin to contribute to the construction of a plurality of ontologies and epistemologies from which readers can choose. This does not mean that research methods and grammar become obsolete, but it encourages nonconformist, different, local ways of thinking and doing.

\subsection{Equal ELT Employment Practices}

Finally, as varieties of English enter mainstream academia, the ELT community should refrain from judging the book (teacher) by its cover (nationality, race, pronunciation, etc.). That is to say, the ELT community has prioritized the "native" English-speaker as the ideal language teacher. Employment opportunities are often reserved for native-speaking nationals from specific countries and (by proxy) specific races (see Kumaravadivelu, 2014). The evolution of the pragmatic contexts of sociolinguistics across the CWE illustrate clearly that one does not have to belong to a particular demographic group to be a proficient user of English. Instead, ELT employment committees should assess the language teacher (regardless of origin) for the quality, cohesion, and applicability of his/her knowledge and skill for the local context. This approach has the potential to address Phillipson's (1998, p. 111) concern that "[...] agents of world English are to some degree facilitating MacDonaldization, and that what is promising for Anglo-American business is threatening to everyone else."

\section{Conclusion}

The machinery of colonization and globalization that initiated the spread of the inner circle English-variety and knowledge economy is part of a multidirectional system as illustrated in Table 1. The same machinery assists or obstructs the proliferation of subaltern varieties of English and marginalized worldviews that could continue to contribute to the homogenization of the CWE. As the circles continue to evolve, sociolinguistic points of convergence occur when the pragmatic contexts of sociolinguistics across the circles become more similar than different; this phenomenon indicates that the CWE are experiencing reciprocal processes of homogenization that contribute to a more equitable notion of world Englishes.

The confluence of topics in this paper could motivate productive additional research projects. For example, to bolster Kumaravadivelu's (2014) personal reflection, the rapid spread of Western university campuses across Asia validates an empirical investigation of the equal opportunity hiring practices of such universities as propellers of the English knowledge economy. In conclusion, revisiting Kachru's original model and reconceptualizing it to assume modular plastic and accommodate the sociolinguistic fluctuations brought about by globalization could make a valuable grounded theoretical contribution to the study of ELT. 


\section{References}

Altbach, P. G. (2004). Globalisation and the university: Myths and realities in an unequal world. Tertiary Education and Management, 10(1), 3-25. https://doi.org10.1023/B:TEAM.0000012239.55136.4b

Altbach, P. G. (2015). Knowledge and education as international commodities. International Higher Education, 28, 2-5. https://doi.org10.6017/ihe.2002.28.6657

Azam, M., Chin, A., \& Prakash, N. (2013). The returns to English-language skills in India. Economic Development and Cultural Change, 61(2), 335-367. https://doi.org10.1086/668277

Belcher, D. D. (2006). English for Specific Purposes: Teaching to perceived needs and imagined futures in worlds of work, study, and everyday Life. TESOL Quarterly, 40(1), 133-156. https://doi.org $10.2307 / 40264514$

Benrabah, M. (2014). Competition between four "world" languages in Algeria. Journal of World Languages, 1(1), 38-59. https://doi.org10.1080/21698252.2014.893676

Bleakley, H. \& Chin, A. (2004). Language skills and earnings: Evidence from childhood immigrants. Review of Economics and Statistics, 86(2), 481-496. https://doi.org 10.1162/003465304323031067

Bovill, C., Jordan, J., \& Watters. N. (2015). Transnational approaches to teaching and learning in higher education: Challenges and possible guiding principles. Teaching in Higher Education, 20(1), 12-23. https://doi.org10.1080/13562517.2014.945162

Canagarajah, A. S. (1999). Resisting linguistic imperialism in English teaching. Oxford: Oxford University Press.

Casale, D., \& Posel, D. (2011). English language proficiency and earnings in a developing country: The case of South Africa. The Journal of Socio-Economics, 40(4), 385-393. https://doi.org10.1016/j.socec.2011.04.009

Choi, P. K. (2003). The best students will learn English: Ultra-utilitarianism and linguistic imperialism in education in post-1997 Hong Kong. Journal of Education Policy, 18(6), 673-694. https://doi.org10.1080/0268093032000145917

Cooper, J. (2006). Of BRICs and brains: Comparing Russia with China, India, and other populous emerging economies. Eurasian Geography and Economics, 47(3), 255-284. https://doi.org10.2747/1538-7216.47.3.255

Crystal, D. (2012). English as a global language. Cambridge: Cambridge University Press.

Deumert, A. (2010). Tracking the demographics of (urban) language shift-an analysis of South African census data. Journal of Multilingual and Multicultural Development, 31(1), 13-35. https://doi.org10.1080/01434630903215125

Dörnyei, Z. (2007). Research methods in applied linguistics. Oxford: Oxford University Press.

Evans, B. A., \& Hornberger, N. H. (2005). No child left behind: Repealing and unpeeling federal language education policy in the United States. Language Policy, 4(1), 87-106. https://doi.org10.1007/s10993-004-6566-2

Feng, A. (2012). Spread of English across Greater China. Journal of Multilingual and Multicultural Development, 33(4), 363-377. https://doi.org10.1080/01434632.2012.661435

Forman, R. (2014). How local teachers respond to the culture and language of a global English as a foreign language textbook. Language, Culture and Curriculum, 27(1), 72-88. https://doi.org10.1080/07908318.2013.868473

García, O. (2005). Positioning heritage languages in the United States. The Modern Language Journal, 89(4), 601-605.

Gardner, S. (2012). "The spread of English internationally since the 1950s." In M. Martin-Jones, A. Blackledge, \& A. Creese (Eds.), The Routledge handbook of multilingualism (pp. 247-264). Routledge: Abingdon.

Giri, R. A. (2014). Changing faces of English: why English is not a foreign language in Nepal. Journal of World Languages, 1(3), 192-209. https://doi.org 10.1080/21698252.2014.989643

Grenier, G. (2015). The value of language skills. IZA World of Labor. Retrieved from $\mathrm{http}$ //wol.iza.org/articles/economic-value-of-language-skills.pdf

Guruz, K. (2011). Higher education and international student mobility in the global knowledge economy. New 
York: SUNY Press.

Heugh, K. (2015). Harmonisation and South African languages: Twentieth century debates of homogeneity and heterogeneity. Language Policy, 1-21. https://doi.org10.1007/s10993-015-9372-0

Hornberger, N., \& Vaish, V. (2009). Multilingual language policy and school linguistic practice: Globalization and English-language teaching in India, Singapore and South Africa. Compare, 39(3), 305-320. https://doi.org 10.1080/03057920802469663

$\mathrm{Hu}, \mathrm{G}$. (2005). English language education in China: Policies, progress, and problems. Language Policy, 4(1), 5-24. https://doi.org 10.1007/s10993-004-6561-7

Hyland, K. (2004). Disciplinary discourses: Social interactions in academic writing. Ann Arbor: University of Michigan Press.

Hyland, K. (2010). English for professional academic purposes: Writing for scholarly publication. In D. Belcher (Ed.) English for Specific Purposes in theory and practice (pp. 83-105). Ann Arbor: University of Michigan Press.

Jenkins, J., Cogo, A., \& Dewey, M. (2011). Review of developments in research into English as a lingua franca. Language Teaching, 44(03), 281-315. https://doi.org10.1017/S0261444811000115

Jeon, M. (2012). English immersion and educational inequality in South Korea. Journal of Multilingual and Multicultural Development, 33(4), 395-408. https://doi.org 10.1080/01434632.2012.661438

Jon, J. E., Lee, J. J., \& Byun, K. (2014). The emergence of a regional hub: Comparing international student choices and experiences in South Korea. Higher Education, 67(5), 691-710. https://doi.org10.1007/s10734-013-9674-0

Jun, H. J., \& Ha, S. K. (2015). Social capital and assimilation of migrant workers and foreign wives in South Korea: The case of Wongok community. Habitat International, 47, 126-135. https://doi.org10.1016/j.habitatint.2015.01.013

Kachru, B. B. (1990a). World Englishes and applied linguistics. World Englishes, 9(1), 3-20. https://doi.org10.1111/j.1467-971X.1990.tb00683.x

Kachru, B. B. (1990b). The alchemy of English: The spread, functions, and models of non-native Englishes. Chicago: University of Illinois Press.

Kachru, B. B. (1996). The paradigms of marginality. World Englishes, 15(3), 241-255. https://doi.org10.1111/j.1467-971X.1996.tb00112.x

Kamwangamalu, N. M. (2000). A new language policy, old language practices: Status planning for African languages in a multilingual South Africa. South African Journal of African Languages, 20(1), 50-60. https://doi.org10.1080/02572117.2000.10587412

Kanno, Y., \& Cromley, J. G. (2013). English language learners' access to and attainment in postsecondary education. TESOL Quarterly, 47(1), 89-121. https://doi.org10.1002/tesq.49

Kim, A. E. (2009). Global migration and South Korea: foreign workers, foreign brides and the making of a multicultural society. Ethnic and Racial Studies, 32(1), 70-92. https://doi.org10.1080/01419870802044197

Kincheloe, J. L. (2008). Critical pedagogy and the knowledge wars of the twenty-first century. International Journal of Critical Pedagogy, 1(1), 1-22. https://doi.org 10.1007/978-94-6091-397-6_29

Knight, J. (2004). Internationalization remodeled: Definition, approaches, and rationales. Journal of Studies in International Education, 8(1), 5-31. https://doi.org 10.1177/1028315303260832

Knight, J. (2015). International universities misunderstandings and emerging models? Journal of Studies in International Education, 19(2), 107-121. https://doi.org 10.1177/1028315315572899

Kratz, C. A. (1989). Genres of power: A comparative analysis of Okiek blessings, curses and oaths. Man, 636-656. https://doi.org 10.2307/2804292

Kulkarni, V. S., \& Hu, X. (2014). English language proficiency among the foreign born in the United States, 1980-2007: Duration, age, cohort effects. International Migration Review, 48(3), 762-800. https://doi.org10.1111/imre.12060/full

Kumaravadivelu, B. (2003). Beyond methods: Macrostages of language teaching. New Haven, CT: Yale University Press. 
Kumaravadivelu, B. (2014). The decolonial option in English teaching: can the subaltern act? TESOL Quarterly, 50(1), 66-85. https://doi.org 10.1002\%2Ftesq.202

Lyotard, J. F. (1984). The postmodern condition: A report on knowledge. Minneapolis: University of Minnesota Press.

Makoni, M. (2016). Mixed reactions to new university language policies. Retrieved from http://www.universityworldnews.com/article.php?story=20160706120904383

McArthur, T. (2001). World English and world Englishes: Trends, tensions, varieties, and standards. Language Teaching, 34(1), 1-20. https://doi.org10.1017/S0261444800016062

McKay, S. L. (2003). Toward an appropriate EIL pedagogy: Re-examining common ELT assumptions. International Journal of Applied Linguistics, 13(1), 1-22. https://doi.org10.1111/1473-4192.00035

Mitchell, N. (2016). Universities around the world offer tuition in English. Retrieved from http://www.bbc.com/news/business-35429233

Modiano, M. (2001). Linguistic imperialism, cultural integrity, and EIL. ELT Journal, 55(4), 339-347. https://doi.org10.1093/elt/55.4.339

Nickerson, C. (2005). English as a lingua franca in international business contexts. English for Specific Purposes, 24(4), 367-380. https://doi.org10.1016/j.esp.2005.02.001

Norton, B. (1997). Language, identity, and the ownership of English. TESOL Quarterly, 31(3), 409-429. https://doi.org10.2307/3587831

Olds, K. (2007). Global assemblage: Singapore, foreign universities, and the construction of a global education hub. World Development, 35(6), 959-975. https://doi.org10.1016/j.worlddev.2006.05.014

Olssen, M., \& Peters, M. A. (2005). "Neoliberalism, higher education and the knowledge economy: From the free market to knowledge capitalism." Journal of Education Policy, 20(3), 313-345. https://doi.org10.1080/02680930500108718

Paltridge, B. (2007). Approaches to genre in ELT. In J. Cummins, \& C. Davison (Eds.), International Handbook of English Language Teaching (pp. 931-943). New York: Springer US.

Pandya, C., McHugh, M., \& Batalova, J. (2011). Limited English proficient individuals in the United States: Number, share, growth, and linguistic diversity. LEP Data Brief. Washington: Migration Policy Institute.

Park, J. K. (2009). "English fever" in South Korea: Its history and symptoms. English Today, 25(1), 50-57. https://doi.org10.1017/S026607840900008X

Park, K. (2014). Foreigners or multicultural citizens? Press media's construction of immigrants in South Korea. Ethnic and Racial Studies, 37(9), 1565-1586. https://doi.org10.1080/01419870.2012.758860

Park, S. J., \& Abelmann, N. (2004). Class and cosmopolitan striving: Mothers' management of English education in South Korea. Anthropological Quarterly, 77(4), 645-672.

Pedraza, S. (2006). Assimilation or transnationalism? Conceptual models of the immigrant experience in America. Cultural Psychology of Immigrants, 419-428.

Peirce, B. N. (1989). Toward a pedagogy of possibility in the teaching of English internationally: People's English in South Africa. TESOL Quarterly, 23(3), 401-420. https://doi.org10.2307/3586918

Pennycook, A. (1996). English, universities, and struggles over culture and knowledge. In R. Hayhoe, \& J. Pan (Eds.), East-West dialogue in knowledge and higher education (pp. 64-80). New York: M. E. Sharpe.

Pennycook, A. (1997). Vulgar pragmatism, critical pragmatism, and EAP. English for Specific Purposes, 16(4), 253-269. https://doi.org10.1016/S0889-4906(97)00019-7

Pennycook, A. (2002). English and the discourses of colonialism. London: Routledge.

Phillipson, R. (1996). Linguistic imperialism: African perspectives. ELT Journal, 50(2), 160-167. https://doi.org10.1093/elt/50.2.160

Phillipson, R. (1997). Realities and myths of linguistic imperialism. Journal of Multilingual and Multicultural Development, 18(3), 238-248. https://doi.org10.1080/01434639708666317

Phillipson, R. (1998). Globalizing English: Are linguistic human rights an alternative to linguistic imperialism? Language Sciences, 20(1), 101-112. https://doi.org10.1080/01434639708666317 
Probyn, M. (2009). "Smuggling the vernacular into the classroom": Conflicts and tensions in classroom codeswitching in township/rural schools in South Africa. International Journal of Bilingual Education and Bilingualism, 12(2), 123-136. https://doi.org 10.1080/13670050802153137

Ricento, T. (2000). Historical and theoretical perspectives in language policy and planning. Journal of Sociolinguistics, 4(2), 196-213. https://doi.org10.1111/1467-9481.00111/full

Ryan, C. (2013). Language use in the United States: 2011. American Community Survey Reports, 2, 1-16.

Seargeant, P., \& Tagg, C. (2011). English on the Internet and a "post-varieties" approach to language. World Englishes, 30(4), 496-514. https://doi.org 10.1111/j.1467-971X.2011.01730.x/full

Seidlhofer, B. (2004). Research perspectives on teaching English as a lingua franca. Annual Review of Applied Linguistics, 24, 209-239. https://doi.org10.1017/S0267190504000145

Slama, R. B. (2012). A longitudinal analysis of academic English proficiency outcomes for adolescent English language learners in the United States. Journal of Educational Psychology, 104(2), 265-285. https://doi.org 10.1037/a0025861

Snow, M. A., Kamhi-Stein, L. D., \& Brinton, D. M. (2006). Teacher training for English as a lingua franca. Annual Review of Applied Linguistics, 26, 261-281. https://doi.org10.1017/S0267190506000134

Song, J. J. (2011). English as an official language in South Korea: Global English or social malady? Language Problems and Language Planning, 35(1), 35-55. https://doi.org10.1075/lplp.35.1.03son

Statistics South Africa. (2011). Census 2011: Census in brief. Retrieved from http://www.statssa.gov.za/census/census_2011/census_products/Census_2011_Census_in_brief.pdf

Sung-Yul Park, J., \& Lo, A. (2012). Transnational South Korea as a site for a sociolinguistics of globalization: Markets, timescales, neoliberalism. Journal of Sociolinguistics, 16(2), 147-164. https://doi.org10.1111/j.1467-9841.2011.00524.x/full

Tse, L. (2001). Why don't they learn English? Separating fact from fallacy in the US language debate. New York: Teachers College Press.

United States Census Bureau. (2016). New Census Bureau Report Analyzes Nation's Linguistic Diversity: Population Speaking a Language Other than English at Home Increases by 140 Percent in Past Three Decades. Retrieved

from https://www.census.gov/newsroom/releases/archives/american_community_survey_acs/cb10-cn58.html

Waltz, K. N. (2000). Globalization and American power. The National Interest, 59, 46-56.

Warschauer, M. (2000). The changing global economy and the future of English teaching. TESOL Quarterly, 34(3), 511-535. https://doi.org10.2307/3587741.

Widdowson, H. G. (1994). The ownership of English. TESOL Quarterly, 28(2), 377-389. https://doi.org10.2307/3587438.

Wildavsky, B. (2010). The great brain race: How global universities are reshaping the world. Princeton: Princeton University Press.

Yoo, O. K. (2005). Discourses of English as an official language in a monolingual society: The case of South Korea. Second Language Studies, 23(2), 1-44. https://doi.orghdl.handle.net/10125/40671

\section{Copyrights}

Copyright for this article is retained by the author(s), with first publication rights granted to the journal.

This is an open-access article distributed under the terms and conditions of the Creative Commons Attribution license (http://creativecommons.org/licenses/by/4.0/). 